\title{
THE INFLUENCE OF THYROID HORMONES ON PROTEIN OXIDATIVE MODIFICATION IN CASE OF EXPERIMENTAL PERIODONTITIS
}

\footnotetext{
Introduction. The inflammatory-dystrophic process in periodontium is accompanied by its hypoxia, which causes the activation of free radical oxidation processes. Tissue destruction in periodontal diseases is considered to be the result of an altered inflammatory/immune response to microbial plaque and involves massive release of neutrophils, reactive oxygen species and enzymes.

The aim of the study - to establish the protein oxidative modification in blood and periodontium in case of periodontitis combined with hyper- and hypothyroidism in rats.

Research Methods. Experimental studies were carry out on 48 mature male, nonliner, white rats, which were divided into the following groups: I - control animals; II - animals with periodontitis; III - animals with periodontitis combined with hyperthyroidism; IV - animals with periodontitis combined with hypothyroidism. Protein oxidative modification (POM) was determined in blood serum and periodontium homogenate by the method of I. F. Meschyshyn.

Results and Discussion. The results of our studies showed that the intensity of the processes of protein oxidative modification was significantly increased in animals of all experimental groups vs control group. The content of aldehyde- and ketone derivatives of the alkali nature changed more pronounced than the content of aldehyde and ketone derivatives of neutral nature.

Conclusions. Thus, the experimental periodontitis is accompanied by a marked increase in the intensity of the protein oxidative modifications both in the homogenate of periodontal tissues and in the blood serum. Imbalance of thyroid hormones increases oxidative stress in experimental periodontitis, especially pronounced in hyperthyroidism.
}

KEY WORDS: periodontitis; thyroid hormones; protein oxidative modification.

INTRODUCTION. Nowadays, an increasing number of publications are suggesting that the direct effectors of the periodontal tissue destructions are components of the host immune system [1]. Tissue destruction in periodontal diseases is considered to be the result of an altered inflammatory/immune response to microbial plaque and involves massive release of neutrophils, reactive oxygen species (ROS) and enzymes. Gingival epithelial cells form the first line of defence in the gingival crevice. So, they have the key role as the protection mechanism of host oral structures from bacterial invasion. Thus, gingival epithelial cells produce an adaptive immune responses and release the chemotaxis factor for neutrophils, antimicrobial peptides and pro-inflammatory cytokines, such as interleukin-8 [2]. Unfortunately, on the other hand, over-expression of these pro-inflammatory cytokines causes collateral tissue damage. ROS produced by activated neutrophils in response to periodonto-pathogenic

(c) V. V. Shcherba, T. Ya. Yaroshenko, R. M. Kubant, M. M. Korda, 2018. bacteria cause serious periodontal tissue lesions, in the context of periodontal disease [3]. Therefore, the balance between antioxidant mechanisms and ROS is very important in periodontal pathogenesis.

The inflammatory-dystrophic process in periodontium is accompanied by its hypoxia, which causes the activation of free radical oxidation processes [4]. On the other hand, the effect of peroxide oxidation on the development of periodontitis is demonstrated through free radical depolymerization of mucopolysaccharides and peroxide destruction of elastic fibers, which leads to atherosclerosis of periodontal vessels [5].

Several authors reported a positive correlation between periodontal tissue damage and high levels of ROS [6, 7]. Hypoxia and inflammation induced higher expression of ROS in primary periodontal ligament fibroblasts [8]. Lipid and protein epitopes generated by lipid peroxidization (adducts) show cross-reactivities against DNA or epitopes expressed on cells undergoing apoptosis. Under normal conditions, antibodies against DNAs or 
apoptotic cells should not exist because they are self-reacting antibodies. Oxidative modifications of biomolecules, however, may be able to generate new epitopes which have molecular similarity and may induce new antibodies which recognize selfantigens. These revelations expanded the possibility of protein oxidative modification involvement to chronic inflammatory diseases, such as periodontitis [9].

That's why the objective of our study was to establish the protein oxidative modification in blood and periodontium in case of periodontitis combined with hyper- and hypothyroidism in rats.

RESEARCH METHODS. Experimental studies were carried out on 48 mature male, nonliner, white rats, that were housed at $(25 \pm 3){ }^{\circ} \mathrm{C}$ and humidity of $(55 \pm 2) \%$, under a constant $12 \mathrm{~h}$ light and dark cycle. Water was available ad libitum. The experimental animals were divided into the following groups: group I - control animals administered intragastrically $1 \%$ solution of starch $(n=12)$; group II - animals with periodontitis (the rats of this group were injected into gum tissue with $40 \mu \mathrm{l}$ of lipopolysaccharide (LPS) E. Coli (Sigma-Aldrich, USA)) 7 times during 2 weeks $(n=12)$ [10]; group III - animals with periodontitis combined with hyperthyroidism. To model the experimental hyperfunction of the thyroid gland, animals received intragastrically L-thyroxine daily in $1 \%$ starch solution at a rate of $10 \mu \mathrm{g} /$ day per $100 \mathrm{~g}$ of body mass for 21 days $(n=12)$ [11]. Starting from the eighth day of experiment, rats were injected into gum tissue with $40 \mu \mathrm{l}$ of LPS E. Coli 7 times during 2 weeks; group IV - animals with periodontitis combined with hypothyroidism. To model the experimental hypofunction of the thyroid gland, animals received intragastrically Merkazolil daily in $1 \%$ starch solution at a rate of $1 \mathrm{mg} /$ day per $100 \mathrm{~g}$ of body mass for 21 days $(n=12)$ [11]. Starting from the eighth day of experiment, rats were injected into gum tissue with $40 \mu \mathrm{l}$ of LPS E. Coli 7 times during 2 weeks. Animal euthanasia was carried out on the $22^{\text {nd }}$ day of the experiment by cardiac puncture under deep anaesthesia. All procedures were conducted according to the European Convention for the Protection of Vertebrate Animals used for Experimental and Other Scientific Purposes [12].

Protein oxidative modification (POM) we determined by the method of I. F. Meschyshyn [13]. In the process of protein oxidative modification aldehyde and ketone groups are formed, which interact with 2,4-dinitrophenylhydrazine (2,4-DNPH) with formation of 2,4-dinitrophenylhydrazones, having a characteristic absorption spectrum. Aldehyde and ketone derivatives of neutral nature recorded at $370 \mathrm{~nm}\left(\mathrm{POM}_{370}\right)$, and alkali nature - $430 \mathrm{~nm}$
$\left(\mathrm{POM}_{430}\right)$. The amount of protein in each sample was determined by the method of $\mathrm{O}$. $\mathrm{H}$. Lowry and co-authors [14]. The content of the phenylhydrazones was calculated using a molar extinction coefficient $\left(2,1 \times 10^{4} \times \mathrm{M}^{-1} \times \mathrm{sm}^{-1}\right)$ and expressed in $\mathrm{mmol}$ per $\mathrm{g}$ of protein.

Statistical processing of digital data was carried out using software Excel (Microsoft, США) and STATISTICA 6.0 (Statsoft, USA). The distribution of data was analyzed according to assessment of normality by Kolmogorov-Smirnov criterion. The obtained values had a parametric distribution, so the difference between the groups was analyzed according to the Students t-criterion. All data were presented as M (mean) $\pm m$ (standard error). A probability level ( $p$ value) of less than 0.05 was considered to be statistically significant.

RESULTS AND DISCUSSION. The results of our studies showed that the intensity of the processes of protein oxidative modification was significantly increased in animals of all experimental groups (Table).

The content of aldehyde and ketone derivatives of neutral nature in blood serum of rats with simulated periodontitis significantly increased by $62.8 \%$, in rats with periodontitis combined with hyperthyroidism by 2.0 times, in rats with periodontitis combined with hypothyroidism - by $80.8 \%$ vs control group. At the same time, this index in blood serum of rats with periodontitis combined with hyperthyroidism was $22.8 \%(p<0.05)$ higher than that of animals with simulated periodontitis without concomitant pathology and $10.6 \%(p<0.05)$ higher than that the index of animals with periodontitis combined with hypothyroidism.

The content of aldehyde- and ketone derivatives of the alkali nature in blood serum of rats with simulated periodontitis significantly increased by $74.1 \%$, in rats with periodontitis combined with hyperthyroidism - by 2.4 times, in rats with periodontitis combined with hypothyroidism - by 2.2 times vs control group. At the same time, this index in blood serum of rats with periodontitis combined with hyperthyroidism was $40.4 \%(p<0.05)$ higher than that of animals with simulated periodontitis without concomitant pathology and $10.9 \%(p<0.05)$ higher than that the index of animals with periodontitis combined with hypothyroidism.

In the periodontal homogenate, the processes of protein oxidative modification were even more intense: the content of aldehyde and ketone derivatives of neutral nature in rats with simulated periodontitis significantly increased by 2.0 times, in rats with periodontitis combined with hyperthyroidism by 2.6 times, in rats with periodontitis combined with hypothyroidism - by 2.5 times vs control group. At 
Table - The indices of protein oxidative modification in rats with periodontitis without concomitant pathology and combined with hyper- and hypothyroidism (M $\pm m, n=12)$

\begin{tabular}{|c|c|c|c|c|}
\hline \multirow[b]{2}{*}{ Index } & \multicolumn{4}{|c|}{ Experimental groups } \\
\hline & Control group & Periodontitis & $\begin{array}{l}\text { Periodontitis } \\
\text { combined with } \\
\text { hyperthyroidism }\end{array}$ & $\begin{array}{l}\text { Periodontitis } \\
\text { combined with } \\
\text { hypothyroidism }\end{array}$ \\
\hline \multicolumn{5}{|c|}{ Blood serum } \\
\hline $\begin{array}{l}\mathrm{POM}_{370}, \mathrm{mmol} / \mathrm{g} \\
\text { of protein }\end{array}$ & $0.78 \pm 0.05$ & $1.27 \pm 0.03^{*}$ & $\begin{array}{c}1.56 \pm 0.05^{\star} \\
p_{1}<0.05\end{array}$ & $\begin{array}{c}1.41 \pm 0.03^{*} \\
p_{2.3}<0.05\end{array}$ \\
\hline $\begin{array}{l}\mathrm{POM}_{430}, \mathrm{mmol} / \mathrm{g} \\
\text { of protein }\end{array}$ & $0.54 \pm 0.02$ & $0.94 \pm 0.05^{\star}$ & $\begin{array}{c}1.32 \pm 0.04^{\star} \\
\mathrm{p}_{1}<0.05\end{array}$ & $\begin{array}{c}1.19 \pm 0.04^{*} \\
p_{2.3}<0.05\end{array}$ \\
\hline \multicolumn{5}{|c|}{ Periodontium homogenate } \\
\hline $\begin{array}{l}\mathrm{POM}_{370}, \mathrm{mmol} / \mathrm{g} \\
\text { of protein }\end{array}$ & $0.51 \pm 0.03$ & $1.01 \pm 0.04^{*}$ & $\begin{array}{c}1.35 \pm 0.04^{*} \\
\mathrm{p}_{1}<0.05\end{array}$ & $\begin{array}{c}1.25 \pm 0.05^{\star} \\
p_{2}<0.05 \\
p_{3}>0.05\end{array}$ \\
\hline $\begin{array}{l}\mathrm{POM}_{430}, \mathrm{mmol} / \mathrm{g} \\
\text { of protein }\end{array}$ & $0.27 \pm 0.02$ & $0.59 \pm 0.05^{*}$ & $\begin{array}{c}0.89 \pm 0,04^{*} \\
p_{1}<0.05\end{array}$ & $\begin{array}{c}0.75 \pm 0.03^{*} \\
\mathrm{p}_{2.3}<0.05\end{array}$ \\
\hline
\end{tabular}

Note. * - significant differences compared to control animals, $p<0.05 ; p_{1}$ - significant differences between the group of periodontitis with the group of periodontitis combined with hyperthyroidism; $p_{2}$ - significant differences between the group of periodontitis with the group of periodontitis combined with hypothyroidism; $p_{3}$ - significant differences between the group of periodontitis combined with hyperthyroidism with the group of periodontitis combined with hypothyroidism.

the same time, this index in periodontal homogenate of rats with periodontitis combined with hyperthyroidism was $33.7 \%(p<0.05)$ higher than that of animals with simulated periodontitis without concomitant pathology and did not differ significantly from the index of animals with periodontitis combined with hypothyroidism.

The content of aldehyde- and ketone derivatives of the alkali nature in periodontal homogenate of rats with simulated periodontitis significantly increased by 2.2 times, in rats with periodontitis combined with hyperthyroidism - by 3.3 times, in rats with periodontitis combined with hypothyroidism by 2.8 times vs control group. At the same time, this index in periodontal homogenate of rats with periodontitis combined with hyperthyroidism was $50.8 \%(p<0.05)$ higher than that of animals with simulated periodontitis without concomitant pathology and $18.7 \%(p<0.05)$ higher than that the index of animals with periodontitis combined with hypothyroidism.

Protein oxidative modifications, also known as protein oxidation, are a major class of protein posttranslational modifications. They are caused by reactions between protein amino acid residues and reactive oxygen species (ROS) or reactive nitrogen species (RNS) and can be classified into two categories: irreversible modifications and reversible modifications [15]. It has been established that under the conditions of oxidative stress and excessive generation of ROS, processes of uncontrolled modification of proteins that cause protein fragmentation, their denaturation, as well as the formation of primary amino acid radicals, which then enter the secondary interaction with adjacent amino acid residues, develop. Protein oxidation was often associated with functional decline of the target proteins [16].

Protein oxidative modification is considered as one of the earliest and reliable markers of oxidative stress [17]. It is believed that the destruction of proteins is an early marker of oxidative tissue damage, as compared to lipid peroxidation, since POM products are more stable than lipid peroxides, which are rapidly metabolized by peroxidases and low molecular weight antioxidants.

Turunen et al. demonstrated that natural antibody IgM that is specific to one of the protein oxidative modification adducts, [18] malondialdehyde-oxidated molecule on oxidated LDL has crossreactivity against gingipain on $P$. gingivalis which is a major causative microbial agent of periodontal diseases.

The changes in the protein oxidative modification in our study are consistent with the data of scientists who observed an increase in the intensity of free radical oxidation in plasma of patients with acute periodontitis compared to healthy individuals $[19,20]$.

Chudinova T. N. notes that the activation of free radical oxidation plays an important role in the development of inflammatory diseases of the periodontal diseases as a direct effect on the periodontal tissue with the subsequent development of the atrophy of the alveolar branch of the jaw as well as a result of changes in the quality of the oral fluid due to the violation of the enzyme-excretory function of the salivary glands. The lipid peroxidation products damage the cells of the endothelium and intima of blood vessels, suppressively affecting the production of prostaglandin 12, thereby contributing to the development of vascular spastic reactions. 
Lipid peroxides promote platelet aggregation and plaque formation due to release from the endothelium of the platelet activating factor, which results in the accumulation of adhesion determinants on blood cells and their mass adherence on vascular endothelium. This worsens the microcirculatory and rheological disorders in the tissues, closing the "vicious cycle" of activation of free radical oxidation [21].

The results of our studies showed an increase in the intensity of peroxide oxidation of proteins under condition of thyroid dysfunction compare to animals with periodontitis without concomitant pathology, more pronounced in rats with periodontitis combined with hyperthyroidism.

Joanta A. and co-authors [22] also showed an increase in the content of carbonyl groups of proteins in the blood, liver, thyroid gland, cardiac and skeletal muscles in experimental hyperthyroidism. However, data of M. Petrulea and coauthors [23] did not establish an increase in the concentration of lipid peroxidation products in the plasma of hyperthyroid rats vs euthyroid group.

There are data that oxidative stress is associated with both hypothyroidism and hyperthyroidism. However, the mechanisms by which oxidative stress is generated under these two clinical conditions are different: an increase in the production of reactive oxygen species under conditions of hyperthyroidism and the low availability of antioxidants in case of hypothyroidism [24].

Thyroid hormones themselves can act as oxidants and cause DNA damage, probably due to the presence of a phenol group [25]. In addition, other mechanisms may be involved [26], in particular, increased expression of the nitric oxide synthase gene with NO hyperproduction and activation of the hepatic nuclear factor kappa-lightchain-enhancer of activated B cells (NF-kB with subsequent increase in the level of cytokines, which causes hyperproduction of ROS. On the other hand, the mechanisms regulated by thyroid hormones carry out fine regulation of the oxidative status by feedback. Among them - the so-called uncoupling proteins (UCP) of the inner membrane of mitochondria. Scientific data suggest that these molecules have antioxidant activity [27]. However, only T3, seems to regulate UCP, while T4 does not affect it [28].

Data on hypothyroidism and oxidative stress are controversial. So, G. Baskol and co-authors in the group of patients with primary hypothyroidism [29] established an increase in concentration of lipid peroxidation products and $\mathrm{NO}$ in blood plasma, decrease in activity of paraoxonase-1 (PON-1). Interestingly, treatment with thyroid hormones reduced the concentration of lipid peroxidation products and increased the activity of PON-1, even though values similar to those observed in the control were not achieved.

An increase in the lipid peroxidation products concentration was also demonstrated under the condition of subclinical hypothyroidism [30]. In this case, an increase in oxidative stress was associated, not only with the decrease in the level of antioxidants, but also with the change in lipid metabolism, since significant correlations between active products of tiobarbituric acis and $\beta$-cholesterol, total cholesterol and triacylglycerols were found.

There are data that high concentrations of TSH directly lead to oxidative stress [31]. A. Haribabu and co-authors reported peroxide oxidation of proteins under the condition of subclinical hypothyroidism (an increase in the concentration of carbonyl groups of proteins) [32]. The research of A. Mancini and co-authors [24], a correlation analysis showed that both an increase in TSH and an increase in the concentration of lipid peroxidation products contributed to the damage to proteins.

CONCLUSIONS. Thus, the experimental periodontitis is accompanied by a marked increase in the intensity of the protein oxidative modifications both in the homogenate of periodontal tissues and in the blood serum. Imbalance of thyroid hormones increases oxidative stress in experimental periodontitis, especially pronounced in hyperthyroidism.

\section{LITERATURE}

1. Human gingival fi broblasts are critical in sustaining infl ammation in periodontal disease / T. Ara, K. Kurata, K. Hirai [et al.] // J. Periodontal Res. - 2009. - 44 (1). P. 21-27.

2. Srivastava N. Point of care - a novel approach to periodontal diagnosis - a review / N. Srivastava, P. A. Nayak, S. Rana // J. Clin. Diagn. Res. - 2017. 11 (8). - P. ZE01-ZE06.
3. Oxidative stress parameters in saliva and its association with periodontal disease and types of bacteria / J. M. Almerich-Silla, J. M. Montiel-Company, S. Pastor [et al.] // Dis. Markers. - 2015. - P. 653537.

4. Романенко И. Г. Генерализованный пародонтит и метаболический синдром. Единство патогенетических механизмов развития / И. Г. Романенко, Д. Ю. Крючков // Крым. терап. журн. - 2011. - № 1. - С. 60-70. 
5. Годована О. І. Аспекти етіології та патогенезу запальних і дистрофрічно-запальних захворювань пародонту / О. І. Годована // Новини стоматології. 2010. - № 3. - C. 69-73.

6. Periodontitis in rats induces systemic oxidative stress that is controlled by bone-targeted antiresorptives / S. Oktay, S. S. Chukkapalli, M. F. Rivera-Kweh [et al.] // J. Periodontol. - 2015. - 86. - P.137-145.

7. Systemic oxidative stress biomarkers in chronic periodontitis: A meta-analysis / Z. Liu, Y. Liu, Y. Song [et al.] // Dis. Markers. - 2014. - Article ID: 931083.

8. Golz L. LPS from P. gingivalis and hypoxia increases oxidative stress in periodontal ligament fibroblasts and contributes to periodontitis / L. Golz, S. Memmert, B. Rath-Deschner // Mediat. Inflamm. - 2014. Article ID 986264.

9. Protein-bound 4-hydroxy-2-nonenal: an endogenous triggering antigen of anti-DNA response / K. Toyoda, R. Nagae, M. Akagawa [et al.] // J. Biol. Chem. - 2007. - 282 (35). - P. 25769-25778.

10. Моисеева Е. Г. Метаболический гомеостаз и имунная реактивность организма в динамике воспаления в тканях пародонта (экспериментальное исследование) : авторефр. на соискание учен. степени д-ра мед. наук / Е. Г. Моисеева. - М. : Российский Университет дружбы народов, 2008. - 45 с.

11. Ратушненко В. О. Функціональна роль тіол-дисульфрідної системи при експериментальному гіпо- i гіпертиреозі / В. О. Ратушненко // Одес. мед. журн. 2010. - № 2 (118). - C. 17-20.

12. European convention for the protection of vertebrate animals used for experimental and other scientific purposes. - Council of Europe. Strasbourg. 1986. - 123. $-52 \mathrm{p}$.

13. Мещишен І. Ф. Метод визначення окиснювальної модифрікації білків плазми (сироватки) крові / І. Ф. Мещишен // Буковин. мед. вісн. - 1998. - 2, № 1. C. $156-158$.

14. Protein measurement with the Folin phenol reagent / O. H. Lowry, N. G. Rosenbrough, A. L. Farr, R. C. Randall // J. Biol. Chem. - 1951. - 193. - P. 265-275.

15. Cai Z. Protein oxidative modifications: Beneficial roles in disease and health / Z. Cai, Jun-Liang Yan // Biochem. Pharmacol. Res. - 2013. - 1. - P. 15-26.

16. Зинь А. Прооксидантно-антиоксидантний гомеостаз і мембранний транспорт у живих організмах / А. Зинь // Вісн. Львів. ун-ту. Серія біологічна. -2012. № 60. - С. 21-39.

17. Лущак В. И. Свободнорадикальное окисление белков и его связь с фрункциональным состоянием организма / В. И. Лущак // Биохимия. - 2007. - 72, № 8. - C. 995-1017.

18. Recognition of Porphyromonas gingivalis gingipain epitopes by natural IgM binding to malondialdehyde modifi ed low-density lipoprotein / S. P. Turunen, O. Kummu, K. Harila [et al.] // PLoS One. - 2012. - 7 (4). e34910.

19. Савельева Н. Н. Состояние системы перекисного окисления липидов и антиоксидантной защиты у больных хроническим генерализованным пародонтитом I-II степени тяжести, сочетающегося с парази- тозами / Н. Н. Савельева // Journal of Education, Health and Sport. - 2015. - 5 (12). - P. 465-476.

20. Сакварелидзе И. Роль свободно-радикального окисления и антиоксидантной защиты в развитии воспалительных процессов в пародонте в женской популяции / И. Сакварелидзе // Актуальные Вопросы Женского Здоровья. - 2014. - № 5. - С. 64-76.

21. Чудинова Т. Н. Обоснование и тактика применения средств метаболической коррекции в комплексном лечении воспалительных заболеваний пародонта у больных с полиморбидной патологией внутренних органов : авторефр. на соискание учен. степени канд. мед. наук / Т. Н. Чудинова. - СПб. : Первый Санкт-Петербургский государственный медицинский университет имени академика И. П. Павлова, 2015. - 17 с.

22. Oxidative stress evidence in rats treated with Thyroxin / A. Joanta, S. Andrei, T. Krausz [et al.] // Buletin USAMV-CN. - 2002. - 57-58. - P. 610-618.

23. Petrulea $M$. Oxidative stress and antioxidant status in hypo- and hyperthyroidism / M. Petrulea, A. Muresan, I. Duncea // Antioxidant Enzyme. - 2012. - 8. P. 197-236.

24. Mancini A. Thyroid hormones, oxidativestress, and inflammation / A. Mancini, C. Di Segni, S. Raimondo // Mediators Inflamm. - 2016. - 6757154.

25. Dobrzyńska M. M. Antioxidants modulate thyroid hormone and noradrenaline-induced DNA damage in human sperm / M. M. Dobrzy'nska, A. Baumgartner, D. Anderson // Mutagenesis. -2004. -19 (4). -P. 325-330.

26. Venditti $P$. Thyroid hormone-induced oxidative stress / P. Venditti, S. DiMeo // Cellular and Molecular Life Sciences. - 2006. - 63 (4). - P. 414-434.

27. Abiophysical study on molecular physiology of the uncoupling proteins of the central nervous system / T. Hoang, M. Kuljanin, M. D. Smith, M. Jelokhani-Niaraki // Bioscience Reports. - 2015. - 35 (4) . - e00226.

28. Potrović N. Thyroxine and triiodothyronine differently affect uncoupling protein-1 content and antioxidant enzyme activities in rat interscapular brown adipose tissue / N. Potrović, G. Cvijić, V. Davidović // Journal of Endocrinology. - 2003. - 176 (1). - P. 31-38.

29. Oxidative stress and enzymatic antioxidant status in patients with hypothyroidism before and after treatment / G. Baskol, H. Atmaca, F. Tanriverdi [et al.] // Experimental and Clinical Endocrinology \& Diabetes. 2007. - 115 (8). - P. 522-526.

30. Serum total antioxidant status and lipid peroxidation marker malondialdehyde levels in overt and subclinical hypothyroidism / A. N. Torun, S. Kulaksizoglu, M. Kulaksizoglu [et al.] // Clinical Endocrinology. - 2009. 70 (3). - P. 469-474.

31. Haribabu A. Evaluation of protein oxidation and its association with lipid peroxidation and thyrotropin levels in overt and subclinical hypothyroidism / A. Haribabu, V. S. Reddy, C. Pallavi // Endocrine. - 2013. 44 (1). - P. 152-157.

32. Dardano A. Recombinant human thyrotropin reduces endothelium-dependent vasodilation in patients monitored for differentiated thyroid carcinoma / A. Dardano, L. Ghiadoni, Y. Plantinga // Journal of Clinical Endocrinology \& Metabolism. - 2006. - 91 (10). P. 4175-4178. 


\section{REFERENCES}

1. Ara, T., Kurata, K., Hirai, K., Uchihashi, T., Uematsu, T., Imamura, Y., Furusawa, K., Kurihara, S. \& Wang, P.L. (2009) Human gingival fi broblasts are critical in sustaining inflammation in periodontal disease. $J$. Periodontal Res., 44 (1), 21-27.

2. Srivastava, N., Nayak, P.A., \& Rana, S. (2017). Point of care - a novel approach to periodontal diagnosis - a review. J. Clin. Diagn Res. 11 (8), ZE01-ZE06.

3. Almerich-Silla, J.M., Montiel-Company, J.M., Pastor, S., Serrano, F., Puig-Silla, M., \& Dasi, F. (2015). Oxidative stress parameters in saliva and its association with periodontal disease and types of bacteria. Dis. Markers, 653537.

4. Romanenko, I.G., \& Kryuchkov, D.Yu. (2011). Generalizovannyy parodontit i metabolicheskiy sindrom. Edinstvo patogeneticheskikh mekhanizmov razvitiya [Generalized periodontitis and metabolic syndrome. The unity of the pathogenetic mechanisms of development] Krymskiy terapevticheskiy zhurnal - Crimean Therapeutic Journal, 1, 60-67 [in Russian].

5. Hodovana, O.I. (2010). Aspekty etiolohii ta patohenezu zapalnykh i dystrofichno-zapalnykh zakhvoriuvan parodontu [Aspects of etiology and pathogenesis of inflammatory and dystrophic-inflammatory periodontal diseases]. Novyny stomatolohii - Dental News, 3, 69-73 [in Ukrainian].

6. Oktay, S., Chukkapalli, S.S., Rivera-Kweh, M.F., Velsko, I.M., Holliday, L.S., \& Kesavalu, L. (2015). Periodontitis in rats induces systemic oxidative stress that is controlled by bone-targeted antiresorptives. $J$. Periodontol., 86, 137-145.

7. Liu, Z., Liu, Y., Song, Y., Zhang, X., Wang, S., \& Wang, Z. (2014). Systemic oxidative stress biomarkers in chronic periodontitis: A meta-analysis. Dis. Markers, Article ID: 931083.

8. Golz, L., Memmert, S., \& Rath-Deschner, B. (2014). LPS from P. gingivalis and hypoxia increases oxidative stress in periodontal ligament fibroblasts and contributes to periodontitis. Mediat. Inflamm., 986264.

9. Toyoda, K., Nagae, R., Akagawa, M., Ishino, K. Shibata, T., Ito, S., Shibata, N., et al. (2007). Proteinbound 4-hydroxy-2-nonenal: an endogenous triggering antigen of anti-DNA response. J. Biol. Chem., 282 (35), 25769-25778.

10. Moyseeva, E.G. (2008). Metabolicheskiy gomeostaz i imunnaya reaktivnost organizma $v$ dinamike vospaleniya $v$ tkanyakh parodonta (eksperimentalnoe issledovanie) [Metabolic homeostasis and immune reactivity of the body in the dynamics of inflammation in periodontal tissues (experimental study)]. Extended $a b$ stract. Moscow: Rossiyskiy Universitet druzhby narodov [in Russian].

11. Ratushnenko, V.O. (2010). Funktsionalna rol tioldysulfidnoi systemy pry eksperymentalnomu hipo- i hipertyreozi [Functional role of thiol-disulphide system in experimental hypo- and hyperthyroidism]. Odeskyi medychnyi zhurnal - Odesa Medical Journal, 2 (118), 17-20.

12. Council of Europe (1986). European convention for the protection of vertebrate animals used for experimental and other scientific purposes. Strasbourg.

13. Meshchyshen, I.F. (1998). Metod vyznachennia okysniuvalnoi modyfikatsii bilkiv plazmy (syrovatky) krovi [Method of determination of oxidative modification of plasma proteins (serum)]. Bukovynskyi med. visnyk Bukovyna Medical Bulletin, 2, 1, 156-158 [in Ukrainian].

14. Lowry, O.H., Rosenbrough, N.G., Farr, A.L., \& Randall, R.C. (1951). Protein measurement with the Folin phenol reagent. J. Biol. Chem., 193, 265-275.

15. Cai, Z., \& Jun-Liang, Y. (2013). Protein oxidative modifications: Beneficial roles in disease and health. Biochem. Pharmacol. Res., 1, 15-26.

16. Zyn, A. (2012). Prooksydantno-antyoksidantnyi homeostaz i membrannyi transport u zhyvykh organizmakh [Prooxidant antioxidant homeostasis and membrane transport in living organisms]. Visnyk Lvivskoho un-tu. Seriia biolohichna - Visnyk of Lviv Univiversity. Biological Series, 60, 21-39 [in Ukrainian].

17. Lushchak, V.I. (2007). Svobodnoradikalnoye okisleniye belkov i ego svyaz s funktsionalnym sostoyaniem organizma [Free radical oxidation of proteins and its connection with the functional state of the body]. Biokhimiia - Biochemistry, 72, 8, 995-1017 [in Russian].

18. Turunen, S.P., Kummu, O., Harila, K., Veneskoski, M., Soliymani, R., Baumann, M., Pussinen, P.J., \& Horkko, S. (2012). Recognition of Porphyromonas gingivalis gingipain epitopes by natural IgM binding to malondialdehyde modifi ed low-density lipoprotein. PLOS One, 7 (4), e34910.

19. Saveleva, N.N. (2015). Sostoyanie sistemy perekisnogo okisleniya lipidov i antioksidantnoy zashchity u bolnykh khronicheskim generalizovannym parodontitom I-II stepeni tyazhesti, sochetayushchegosya s parazitozami [The state of the system of lipid peroxidation and antioxidant protection in patients with chronic generalized periodontitis I-II severity, combined with parasitosis]. Journal of Education, Health and Sport, 5 (12), 465-476 [in Russian].

20. Sakvarelidze, I. (2014). Rol svobodno-radikalnogo okisleniya i antioksidantnoy zashchity $v$ razvitii vospalitelnykh protsessov $v$ parodonte $v$ zhenskoy populyatsii [The role of free radical oxidation and antioxidant protection in the development of inflammatory processes in the periodontium in the female population]. Aktualnye Voprosy Zhenskogo Zdorovya - Current Issues of Women's Health, 5, 64-76 [in Russian].

21. Chudinova, T.N. (2015). Obosnovanie i taktika primeneniya sredstv metabolicheskoy korrektsii v kompleksnom lechenii vospalitelnykh zabolevaniy parodonta $\mathrm{u}$ bolnykh s polimorbidnoy patologiyey vnutrennykh organov [Substantiation and tactics of the use of metabolic correction in the complex treatment of inflammatory periodontal diseases in patients with polymorbid pathology of internal organs]. Extended abstract. SaintPetersburg: The First St. Petersburg State Medical University named after Academician I.P. Pavlov [in Russian].

22. Joanta, A., Andrei, S., Krausz, T., Filip, A., \& Suciu, S. (2002). Oxidative stress evidence in rats treated with. thyroxin. Buletin USAMV-CN, 57-58, 610618.

23. Petrulea, M., Muresan, A., \& Duncea, I. (2012). Oxidative stress and antioxidant status in hypo- and hyperthyroidism. Antioxidant Enzyme, 8, 197-236.

24. Mancini, A., Di Segni, C., \& Raimondo, S. (2016). Thyroid hormones, oxidativestress, and inflammation. Mediators Inflamm., 6757154. 
25. Dobrzyńska, M.M., Baumgartner, A., \& Anderson, D. (2004). Antioxidants modulate thyroid hormone and noradrenaline-induced DNA damage in human sperm. Mutagenesis, 19 (4), 325-330.

26. Venditti, P., \& DiMeo, S. (2006). Thyroid hormoneinduced oxidative stress. Cellular and Molecular Life Sciences, 63 (4), 414-434.

27. Hoang, T., Kuljanin, M., Smith, M.D., \& JelokhaniNiaraki, M. (2015). Abiophysical study on molecular physiology of the uncoupling proteins of the central nervous system. Bioscience Reports, 35 (4), e00226.

28. Potrović, N., Cvijić, G., \& Davidović, V. (2003). Thyroxine and triiodothyronine differently affect uncoupling protein-1 content and antioxidant enzyme activities in rat interscapular brown adipose tissue. Journal of Endocrinology, 176 (1), 31-38.

29. Baskol, G., Atmaca, H., Tanriverdi, F., Baskol, M., Kocer, D., \& Bayram, F. (2007). Oxidative stress and enzymatic antioxidant status in patients with hypothyroidism before and after treatment. Experimental and Clinical Endocrinology \& Diabetes, 115 (8), 522-526.

30. Torun, A.N., Kulaksizoglu, S., Kulaksizoglu, M. Pamuk, B.O., Isbilen, E.N., \& Tutuncu, N.B. (2009). Serum total antioxidant status and lipid peroxidation marker malondialdehyde levels in overt and subclinical hypothyroidism. Clinical Endocrinology, 70 (3), 469-474.

31. Haribabu, A., Reddy, V.S., \& Pallavi C. (2013). Evaluation of protein oxidation and its association with lipid peroxidation and thyrotropin levels in overt and subclinical hypothyroidism. Endocrine, 44 (1), 152-157.

32. Dardano, A., Ghiadoni, L., \& Plantinga Y. (2006). Recombinant human thyrotropin reduces endotheliumdependent vasodilation in patients monitored for differentiated thyroid carcinoma. Journal of Clinical Endocrinology \& Metabolism, 91 (10), 4175-4178.

\section{ВПЛИВ ТИРЕОЇДНИХ ГОРМОНІВ НА ОКИСНЮВАЛЬНУ МОДИФІКАЦІЮ ПРОТЕЇНІВ ЗА УМОВ ЕКСПЕРИМЕНТАЛЬНОГО ПАРОДОНТИТУ}

\section{Резюме}

Вступ. Запально-дистрофрічний процес у пародонті супроводжується гіпоксією, що викликає активацію вільнорадикальних процесів окиснення. Руйнування тканин при пародонтиті є результатом запально-імунної відповіді на мікробну інвазію і супроводжується масовим вивільненням нейтрофрілів, активних форм оксигену та ензимів.

Мета дослідження - встановити ступінь окиснювальної модифрікації протеїнів у крові й пародонті при пародонтиті в поєднанні з гіпер- і гіпотиреозом у щурів.

Методи дослідження. Експериментальні дослідження проводили на 48 статевозрілих нелінійних білих щурах-самцях, яких було поділено на такі групи: 1-ша - контрольна; 2-га - тварини з модельованим пародонтитом; 3-тя - тварини з модельованим пародонтитом на тлі гіпертиреозу; 4-та - тварини 3 модельованим пародонтитом на тлі гіпотиреозу. Окиснювальну модифрікацію протеїнів визначали за методом І. Ф. Мещишена.

Результати й обговорення. Результати проведених досліджень показали, що інтенсивність процесів окиснювальної модифрікації протеїнів була значно підвищена у тварин усіх експериментальних груп відносно контрольної. При цьому вміст альдегідо- $і$ кетонопохідних основного характеру змінювався більш виражено, ніж вміст альдегідо- та кетонопохідних нейтрального характеру.

Висновки. Експериментальний пародонтит супроводжується помітним збільшенням інтенсивності окиснювальної модифрікації протеїнів як у гомогенаті пародонта, так і в сироватці крові. Дисбаланс тиреоїдних гормонів підвищує оксидативний стрес при експериментальному пародонтиті, особливо виражено - при гіпертиреозі.

КЛЮЧОВІ СЛОВА: пародонтит; тиреоїдні гормони; окиснювальна модифрікація протеїнів. 


\section{ВЛИЯНИЕ ТИРЕОИДНЫХ ГОРМОНОВ НА ОКИСЛИТЕЛЬНУЮ МОДИФИКАЦИЮ ПРОТЕИНОВ В УСЛОВИЯХ ЭКСПЕРИМЕНТАЛЬНОГО ПАРОДОНТИТА}

\section{Резюме}

Вступление. Воспалительно-дистрофический процесс в пародонте сопровождается гипоксией, что вызывает активацию свободнорадикальных процессов окисления. Разрушение тканей при пародонтите является результатом воспалительно-иммунного ответа на микробную инвазию и сопровождается массовым высвобождением нейтрофилов, активных фрорм кислорода и энзимов.

Цель исследования - установить степень окислительной модификации протеинов в крови и пародонте при пародонтите в сочетании с гипер- и гипотиреозом у крыс.

Методы исследования. Экспериментальные исследования проводили на 48 половозрелых нелинейных белых крысах-самцах, которые были разделены на следующие группы: 1-я - контрольная; 2-я - животные с моделируемым пародонтитом; 3-я - животные с моделируемым пародонтитом на фроне гипертиреоза; 4-я - животные с моделируемым пародонтитом на фроне гипотиреоза. Окислительную модификацию протеинов определяли по методу И. Ф. Мещишена.

Результаты и обсуждение. Результаты проведенных исследований показали, что интенсивность процессов окислительной модификации протеинов была значительно повышена у животных всех экспериментальных групп относительно контрольной. При этом содержание альдегидо- и кетонопроизводных основного характера менялось более выражено, чем содержание альдегидо- и кетонопроизводных нейтрального характера.

Выводы. Экспериментальный пародонтит сопровождается заметным увеличением интенсивности окислительной модификации протеинов как в гомогенате пародонта, так и в сыворотке крови. Дисбаланс тиреоидных гормонов повышает оксидативный стресс при экспериментальном пародонтите, особенно выражено - при гипертиреозе.

КЛЮЧЕВЫЕ СЛОВА: пародонтит; тиреоидные гормоны; окислительная модификация протеинов.

Received 17.10.18

Address for correspondence: V. V. Shcherba, I. Horbachevsky Ternopil State Medical University, Maidan Voli, 1, Ternopil, 46001, Ukraine, e-mail: shcherba@tdmu.edu.ua. 